\title{
A Call to Develop Course-Based Undergraduate Research Experiences (CUREs) for Nonmajors Courses
}

Cissy J. Ballen, ${ }^{\dagger *}$ Jessamina E. Blum ${ }^{\dagger}$ Sara Brownell ${ }^{\ddagger}$ Sadie Hebert, ${ }^{\dagger}$ James Hewlett, § Joanna R. Klein," Erik A. McDonald," Denise L. Monti," Stephen C. Nold, @ Krista E. Slemmons, ** Paula A. G. Soneral, ${ }^{+t}$ and Sehoya Cotner ${ }^{\dagger}$

'Department of Biology Teaching and Learning, University of Minnesota, Minneapolis, MN 55455; ¡School of Life Sciences, Arizona State University, Tempe, AZ 85281; `Department of Science and Technology, Finger Lakes Community College, Canandaigua, NY 14424; "Department of Biology \& Biochemistry, University of Northwestern, St. Paul, MN 55113; 'School of Interdisciplinary Arts and Sciences, University of Washington, Tacoma, WA 98402; \#Department of Biology, University of Alabama, Birmingham, AL 35233; @ Department of Biology, University of Wisconsin-Stout, Menomonie, WI 54751; ** Department of Biology, University of Wisconsin-Stevens Point, Stevens Point, WI 54481; "+Department of Biological Sciences, Bethel University, St. Paul, MN 55112

\begin{abstract}
Course-based undergraduate research experiences (CUREs) for non-science majors (nonmajors) are potentially distinct from CUREs for developing scientists in their goals, learning objectives, and assessment strategies. While national calls to improve science, technology, engineering, and mathematics education have led to an increase in research revealing the positive effects of CUREs for science majors, less work has specifically examined whether nonmajors are impacted in the same way. To address this gap in our understanding, a working group focused on nonmajors CUREs was convened to discuss the following questions: 1) What are our laboratory-learning goals for nonmajors? 2) What are our research priorities to determine best practices for nonmajors CUREs? 3) How can we collaborate to define and disseminate best practices for nonmajors in CUREs? We defined three broad student outcomes of prime importance to the nonmajors CURE: improvement of scientific literacy skills, proscience attitudes, and evidence-based decision making. We evaluated the state of knowledge of best practices for nonmajors, and identified research priorities for the future. The report that follows is a summary of the conclusions and future directions from our discussion.
\end{abstract}

\section{INTRODUCTION}

Science educators face the unique challenge of engaging large undergraduate populations with diverse educational backgrounds and interests in science, technology, engineering, and mathematics (STEM). Previous work has demonstrated the positive influence of individual undergraduate research experiences on students' performance and attitudes (Lopatto, 2007; Russell et al., 2007; Hanauer and Hatfull, 2015), but such opportunities are typically not scalable or widely accessible. However, course-based undergraduate research experiences (CUREs) meet this need to expand research experiences to a larger number of students. CUREs are laboratory-learning environments that involve an entire class in the investigation of an original research question that has broad scientific importance (Auchincloss et al., 2014; Bangera and Brownell, 2014). While CUREs have historically been developed with the aim to increase persistence and interest in science for majors, there is recent interest in exploring the impact of CUREs on non-science majors, or nonmajors. Previous work demonstrates a multitude of differences between majors and nonmajors (Sundberg and Dini, 1993; Sundberg et al., 1994; Klymkowsky, 2005; Nehm and Reilly, 2007; Cook and Mulvihill, 2008;
CBE Life Sci Educ June 1, 2017 16:mr2 DOI:10.1187/cbe.16-12-0352

*Address correspondence to: Cissy J. Ballen (balle027@umn.edu).

(c) 2017 C. J. Ballen et al. CBE-Life Sciences Education (c) 2017 The American Society for Cell Biology. This article is distributed by The American Society for Cell Biology under license from the author(s). It is available to the public under an Attribution-Noncommercial-Share Alike 3.0 Unported Creative Commons License (http:// creativecommons.org/licenses/by-nc-sa/3.0). "ASCB ${ }^{\circ}$ " and "The American Society for Cell Biology $\circledR^{\prime \prime}$ are registered trademarks of The American Society for Cell Biology. 
Knight and Smith, 2010; Cotner et al., 2017), so a consideration of these differences will be important to achieve desired student outcomes and highlight research priorities for nonmajors CUREs. Because nonmajors may not need the lab- or field-specific skills taught in a CURE in their future careers, it is not our objective to train nonmajors to become scientists. However, they may acquire select skills, such as associated learning gains, from classroom and laboratory experiences that improve their perceptions of the discipline and increase science literacy. Previous work exploring the influence of these elements is lacking, and so research into evidence-based pedagogies for nonmajors is essential to our national efforts to improve the science literacy of all students in higher education.

During a breakout discussion at the CUREnet meeting in Cold Spring Harbor in 2014, a group of educators identified "CUREs for nonmajors" as potentially distinct-in goals, learning objectives, and assessment strategies-from CUREs for developing scientists. On the heels of that discussion, several faculty at the University of Minnesota proposed hosting a workshop for like-minded colleagues specifically addressing CUREs for nonmajors. A working group of biology education researchers and course developers convened to identify best practices for CUREs specifically for nonmajors. Each individual brought a diverse perspective reflecting experience from different university environments (e.g., faculty from a large university, small university, community college, religious college). Here, we identify the laboratory-learning goals for nonmajors developed by this working group and discuss the state of knowledge of best practices for nonmajors CUREs. With this baseline information, we identify pressing research priorities for the future and recommend tools to align research questions with student outcomes.

\section{LABORATORY-LEARNING GOALS FOR NONMAJORS}

One of the aims of the meeting focused on the question What are the laboratory-learning goals for nonmajors, and how can a CURE accomplish these goals? The three outcomes came as a result of a daylong discussion with 12 faculty who develop authentic research experiences for undergraduate nonmajors in classroom contexts (Supplemental Material). Before we convened on the first day, participants prepared by reading papers about the topic of science literacy (Miller, 2004; Wright, 2005; Klymkowsky, 2005; Feinstein et al., 2013) and contributing what they consider relevant publications to a shared annotated bibliography. Before the discussion on proposed learning goals for nonmajors, Cotner led a discussion on learning outcomes for nonscientists and the public according to the assigned readings and participants' existing knowledge.

After the discussion, we concluded that the desired outcomes resulting from nonmajors participation in laboratory or research environments are students characterized by having developed the following:

- Scientific literacy skills, or the ability to access and make sense of science relevant to their daily lives (Feinstein et al., 2013). The United States is exceptional in requiring that students take science as part of general education courses. In turn, U.S. adults have significantly higher levels of scientific literacy compared with adults in countries that do not require students to take science courses at the university level, a fact that underscores the importance of undergraduate science courses for all students (Miller, 2004).

- Proscience attitudes, or positive attitudes toward scientists and scientific research (Osborne et al., 2003). The positive correlation between the public understanding of science and public opinion of science suggests that, across cultures, proscience attitudes about science and technology contribute to actual knowledge (Allum et al., 2008).

- Evidence-based decision-making skills, or solving personally meaningful problems with evidence-based solutions (Feinstein et al., 2013). After graduation from a college or university, nonmajors will regularly engage with scientific issues relevant to their daily lives and make decisions using science that impact them and their communities (Feinstein et al., 2013).

Given the importance of developing these qualities for nonmajors, well-designed scalable research experiences embedded in introductory science classes may support the development of these attitudes and skills, as previously demonstrated in majors classrooms. However, practices found to be effective for majors may not engage nonmajors, and we urge educators to consider the distinct learning goals of nonmajors as they develop curricula. Educators should also strive to establish practices that lead nonmajors students to experience the realities of empirical research-to grapple with failure, experience the inherent messiness of science, and understand the process of research from the conception of a testable question to the evidence-based conclusion drawn from experimental results.

Previous work demonstrates that participation in research as an undergraduate leads to positive student outcomes for science majors (e.g., Hathaway et al., 2002; Zydney et al., 2002; Russell et al., 2007; Espinosa, 2011), prompting calls to science education reform that recommend the incorporation of research experiences into curricula (American Association for the Advancement of Science, 2011; Brownell and Kloser, 2015; Shapiro et al., 2015). Undergraduate research experiences have historically taken the form of individual research apprenticeships, either in individual faculty labs or departments (e.g., Research Experiences for Undergraduates Program funded by the National Science Foundation), through summer research experiences (Lopatto, 2007; Hernandez et al., 2013), or, when possible, direct engagement with the natural world (e.g., through field experiences or research; Smith, 2004; Boyle et al., 2007). Although these types of research experiences lead to documented benefits (Hathaway et al., 2002; Zydney et al., 2002; Russell et al., 2007; Espinosa, 2011), they are not logistically feasible for reaching a large number of students (Wood, 2003; Desai et al., 2008).

\section{COURSE-BASED UNDERGRADUATE RESEARCH EXPERIENCES}

CUREs are a type of scalable laboratory-learning environment that expose students to the process of research early in their college careers (Auchincloss et al., 2014; Bangera and Brownell, 2014). According to Auchincloss et al. (2014), CUREs possess five defining dimensions: 1) Iteration. Cycles of experimental repetition followed by critical evaluation of data are inherent to the nature of science and, in the context of a CURE, may reveal biological variation or trends. 2) Collaboration. Students work cooperatively to ask research questions and tackle complex 
problems with other students and the laboratory and/or course instructor. 3) Scientific process. Students learn scientific practices by engaging in science investigations. 4) Broad relevance. Students conduct research that has relevance to the larger scientific or local community. 5) Discovery. Students work with novel data and a question to arrive at an answer unknown to the student, instructor, and broader scientific community.

Although other laboratory-learning environments may integrate one or more of these features, a well-designed CURE is characterized by encompassing all five dimensions. In contrast, the traditional "cookbook" laboratory course, in which recipe-like instructions lead students through investigative experiences, sometimes involves scientific practices or some form of collaboration (Brownell et al., 2012), although it lacks elements of both discovery and broad relevance given its "known answer." However, the hallmark of a CURE is really the emphasis on seeking discoveries that have broad relevance, making these not two independent dimensions but rather one (Brownell and Kloser, 2015; Corwin et al., 2015).

When the meeting participants discussed the defining features of a CURE as outlined in Auchincloss et al. (2014), we acknowledged that the relative importance of specific dimensions of a CURE have yet to be empirically tested. In achieving the stated goals for nonmajors, can laboratory activities lacking one or more dimensions be sufficient for achieving overarching objectives of improving scientific literacy skills, evidence-based decision-making skills, and promoting proscience attitudes? For example, two common laboratory activities resemble CUREs as they were defined earlier but differ notably for lacking one or more CURE-defining aspects, and so we will define them for the first time here: In student-led inquiry laboratories, students ask their own questions within an established model system. However, there is no expectation to ask novel questions or generate original results or inform any community beyond the classroom (Minner et al., 2010). In these laboratories, it will be important to test whether providing students with the autonomy to ask their own questions outweighs the benefits they

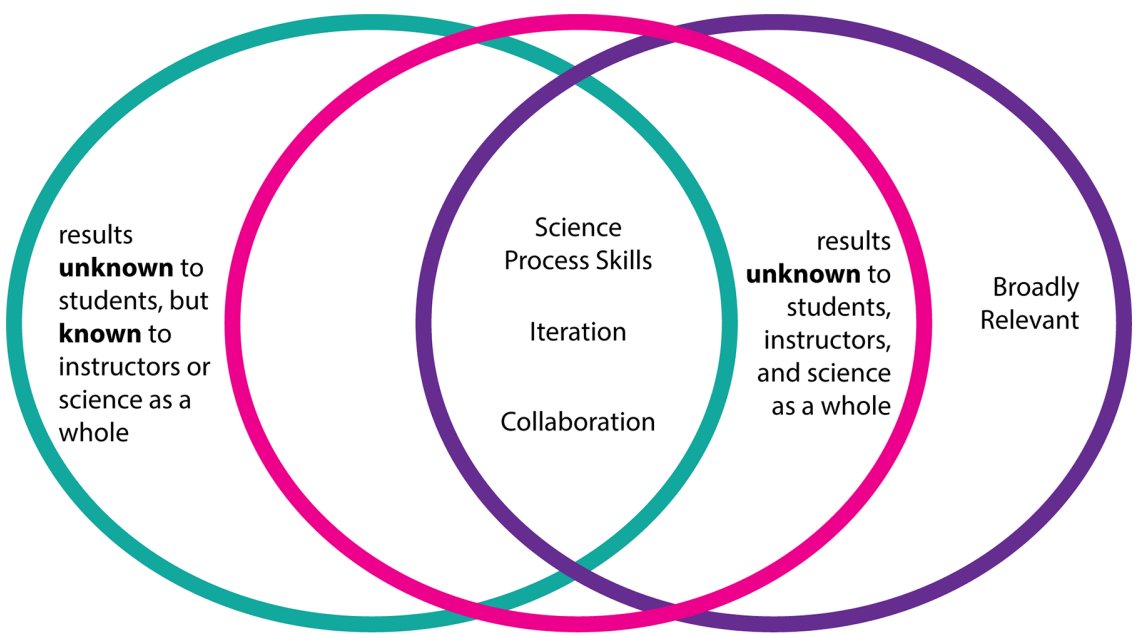

Inquiry Discovery-based Inquiry

FIGURE 1. Differences and similarities among inquiry-based labs present students a range of opportunities for engaging in the process of science.
CURE

experience by contributing to broader scientific discovery. In discovery-based inquiry laboratories, students ask novel questions but findings are also not considered broadly relevant, because there is no expectation to disseminate results. A discovery-based inquiry laboratory differs from a CURE, in which students ask novel questions and are expected to share their findings with communities outside the classroom (Figure 1). In these laboratories, we may expect that students who do not disseminate their results benefit from the laboratory experience as much as those who, for example, speak about their conclusions to the local community or provide their raw data to a research laboratory.

Until now, STEM education researchers have focused primarily on the effects of CUREs on developing scientists, or those who intend to obtain a degree in a science field. Such studies indicate that CUREs increase student performance, retention, self-reported learning, and ability to "think like a scientist" (Jordan et al., 2014; Brownell et al., 2015). For these reasons, we would expect that students poised to flow outside the "science pipeline" may also benefit from laboratory research experiences. Among these students are nonmajors, for whom we have little information regarding best practices. We identify here the differences between majors and nonmajors, highlight gaps in our understanding of best practices for nonmajors, and consider research priorities that will inform how we teach future students.

\section{WHAT DO WE KNOW ABOUT NONMAJORS?}

Before developing CUREs for nonmajors, it is important to understand how the student population differs from majors students, a group that has been studied extensively to identify best science-teaching practices. Knowledge of the differences between majors and nonmajors can inform our learning goals and approaches when educating both student cohorts. Some authors have focused on differences between majors and nonmajors, emphasizing that nonmajors have less interest in STEM (Knight and Smith, 2010); motivation to learn and participate in science (Glynn et al., 2011); understanding of the nature of science (Partin et al., 2013); and science content knowledge (Knight and Smith 2010; Medina et al., 2014). Still others have noted differences in how nonmajors compared with majors perceive socially polarizing topics in the sciences, such as human evolution (Miller, 2004; Paz-y-mino and Espinosa, 2010) and anthropogenic climate change (Kahan, 2010). Smith et al. (2004) confirm that nonmajors primarily enroll in STEM courses to fulfill graduation requirements rather than to satiate curiosity or obtain desired skills. Nonmajors at the University of Minnesota are less likely than majors to see science as personally relevant, and they are more likely to express misconceptions about the nature of science (Cotner et al., 2017). To shift this perception, along with others, the development of CUREs for nonmajors should focus on the elements of scientific 
literacy that are personally and culturally relevant, such as public policy (Martin and Richards, 1995; Oreskes, 2004), personal health (Chervenak and McCullough, 1990; Larson et al., 2011), and place-based exercises (which incorporate the geographic and cultural meanings of a location as context for the scientific study; Semken and Freeman, 2008). Further, there is a positive correlation between attitudes toward science and knowledge of science, such that, across cultures, positive attitudes lead to increased understanding of scientific concepts (Allum et al., 2008; Partin et al., 2013). Furthermore, nonmajors, who represent a range of interests beyond the sciences, are likely to exhibit multiple diverse perspectives (Cotner et al., 2017). In light of these broad differences between majors and nonmajors, we expect course design elements of CUREs that emphasize personal relevance and promote inclusive environments to particularly improve the learning and performance of nonmajors. Further, diverse perspectives may lead to more diverse outcomes following stratification by major, and future research will need to carefully untangle and address these differences in the evaluation of CURE outcomes.

\section{THE STATE OF KNOWLEDGE OF BEST PRACTICES FOR NONMAJORS CURES}

Institutional resources may favor investment in science majors over nonmajors, and science educators are bound to prioritize the development of future scientists. As a consequence, literature on nonmajors' experience in STEM courses overall (to say nothing of CUREs specifically), while informative, is limited. We know very little about how these individuals approach course-based research, what features of a CURE are likely to promote our desired outcomes, or how an ideal CURE for a nonmajor may differ from that of a developing scientist. Cotner and Hebert (2016) document how nonmajors in a discovery-based inquiry experience value the "authenticity" of research over other, cookbook-style lab activities; however, this work lacked broad relevance and was not, by definition, a CURE.

Clearly, further work is needed to determine how inquiry in general, and course-based research experiences specifically, influence scientific literacy. To start, we must determine whether nonmajors CUREs should be considered distinct from majors CUREs. Following that, and if warranted, we can address specific questions about the design and implementation of CUREs for nonmajors, to unpack which, if any, design features

\footnotetext{
${ }^{1}$ The term "authenticity" appears in a variety of reports focused on the undergraduate research experience, including the President's Council of Advisors on Science and Technology report Engage to Excel (2012). Definitions of "authenticity" may vary with respect to the context in which it is used and may show variability among professionals and institutions. This variability may also exist in the application of the definition to majors and nonmajors. Employing the term "authentic" may assume that there is an experience that is "inauthentic." The lack of consensus with respect to defining the term may reflect the nonbinary nature of the term, and may explain why work on defining the term often focuses on higher conceptual levels, such as the novelty of the research question and the degree to which students engage in the process of science (Spell et al., 2014). In light of the variability and potential lack of consensus on developing an operational definition of "authentic," it may be more appropriate to focus on the characterization of the structure of the undergraduate research experience from the student perspective and then employ those defining features as a way to evaluate the authenticity of the experience. For CUREs, there have been recent reports that outline the consensus features of this form of the undergraduate research experience (Auchincloss et al., 2014; Bangera and Brownell, 2014).
}

or implementation strategies are more or less critical for achieving learning outcomes for nonmajors. Realistically, a onesemester nonmajors science course may be students' only formal scientific training in college and perhaps the only opportunity to experience scientific research. Thus, we can investigate important questions about how nonmajors engage in the research, and how a research experience contributes to scientific literacy in our nonmajors population (e.g., Cotner and Hebert, 2016).

\section{RESEARCH PRIORITIES FOR DETERMINING BEST PRACTICES FOR NONMAJORS CURES}

There are a number of national CUREs that target both majors and nonmajors (e.g., SEA-PHAGES, Small World Initiative, Community College Undergraduate Research Initiative), and many individual faculty members who use CUREs (e.g., through the Course-based Undergraduate Research Experiences Network, www.curenet.cns.utexas.edu). Despite the growing implementation of CUREs, the focus of research stemming from these efforts has either not identified nonmajors students in the analyses or these data are unpublished. If the widespread adoption of CUREs continues to expand, faculty and students will benefit from research focused specifically on the experience of nonmajors, because we anticipate that their needs differ from majors students-even if these different needs do not require different CUREs. Ongoing CURE programs and existing evaluative tools designed to assess the effects of CUREs on majors lay the groundwork for testing similar hypotheses about nonmajors (for a recent summary of assessment tools, see Brownell and Kloser, 2015; Shortlidge and Brownell, 2016), and evaluating best practices for one group of students may inform best practices for the other (Table 1).

\section{ALIGNING EXISTING ASSESSMENT TOOLS WITH GOALS}

Assessment tools allow instructors to ask specific questions that align teaching goals with practical outcomes (for a comprehensive list of possible CURE outcomes, see Corwin et al., 2015). In the context of nonmajors CURE research, we hope to achieve three broad objectives: the improvement of scientific research literacy skills, proscience attitudes, and evidence-based decision making. Here, we discuss assessments that are relevant to those central objectives or that can document how student perceptions, attitudes, and academic performance can change in response to CUREs.

1. Scientific literacy skills can be measured using an existing instrument called the Test of Scientific Literacy Skills, which quantifies student proficiency in using scientific concepts beyond the classroom (Gormally et al., 2012). Alternatively, instructors can measure nonmajors knowledge of relevant course content after different laboratory experiences as a proxy for scientific literacy. Though this method has been tested on majors students (Shaffer et al., 2010, 2014; Brownell et al., 2012; Kloser et al., 2013; Jordan et al., 2014), who exhibit knowledge gains on related topics after experiencing a CURE, research has not demonstrated whether nonmajors benefit in the same way. We also caution that science content knowledge differs markedly from science literacy skills, and the two should not be used interchangeably (Klymkowsky, 2005). Future research will also 
TABLE 1. Specific research questions for future consideration pooled into two broad categories of inquiry related to nonmajors students: improving CURE design elements and addressing unique learning gains or course outcomes

\begin{tabular}{|c|c|}
\hline Pooled research category & Research questions \\
\hline $\begin{array}{l}\text { Improving CURE design elements } \\
\text { for nonmajors }\end{array}$ & $\begin{array}{l}\text { What features of a CURE are critical for achieving our desired nonmajors-specific outcomes? Specifically, } \\
\text { should a CURE be discovery based and broadly relevant, or is student-led inquiry sufficient for } \\
\text { achieving our overarching goals for science literacy? } \\
\text { How do nonmajors compare with majors with respect to motivation, interest, engagement, self-efficacy, } \\
\text { and scientific products (results, interpretation, etc.)? If there are differences, can we use knowledge of } \\
\text { these differences to better tailor the research experience for nonmajors? } \\
\text { Do nonmajors require additional knowledge in preparation for a CURE? If so, what steps are needed to } \\
\text { deliver this information? }\end{array}$ \\
\hline $\begin{array}{l}\text { Addressing unique learning gains or } \\
\text { course outcomes for nonmajors }\end{array}$ & $\begin{array}{l}\text { Do CUREs improve nonmajors science literacy, proscience attitudes, or evidence-based decision-making } \\
\text { skills? } \\
\text { What are the unique learning needs and learning gains of a nonmajor vs. a major in the context of a CURE? } \\
\text { In conducting course-based research, do nonmajors see themselves-even briefly-as members of the } \\
\text { scientific community? Or, by doing small tasks that contribute to a larger project, do they see } \\
\text { themselves as peripheral participants in scientific research? } \\
\text { Do nonmajors recognize the value of a research experience? }\end{array}$ \\
\hline
\end{tabular}

profit by examining the extent to which CUREs affect nonmajors scientific literacy by measuring gains in analytical skills (Shaffer et al., 2010; Bascom-Slack et al., 2012; Brownell et al., 2012; Hanauer et al., 2012; Kloser et al., 2013).

2. Proscience attitudes can be directly measured by the Test of Science-Related Attitudes, which quantifies favorable attitudes toward science and scientists (Fraser, 1978). Cotner et al. (2017) found a significant difference between majors and nonmajors perceptions of scientists and scientific methods, such that nonmajors were more likely to view science as a static discipline that is mostly "an accumulation of facts, rules and formulas" and that is "not connected to non-science fields such as history, literature, economics, or art." Further, they found nonmajors more likely than majors to hold naïve and inaccurate perceptions about the nature of science and to see science as less personally relevant. Given these misconceptions, nonmajors student populations may particularly benefit from exposure to CUREs with the potential to contribute new scientific knowledge. Such contributions may instill a greater appreciation for science as both a process and a discipline. However, the lack of studies on this and other metrics means that all we can do is point to the possibility that CUREs may benefit nonmajors students in ways that have not been quantified. Rigorous research on a wide range of inquiry-based experiences-including CUREs-is required if our studies aim to evaluate the generality of different impacts.

Prior research demonstrates CUREs contribute to proscience attitudes among majors by promoting student motivation to do science (Alkaher and Dolan, 2014; Shaffer et al., 2014), collaboration skills or perceptions about interactions with peers (Shaffer et al., 2010, 2014; Alkaher and Dolan, 2014), and sense of belonging to a larger community (Jordan et al., 2014; Shaffer et al., 2014). Overall positive shifts in sense of belonging and motivation are likely to have positive impacts overall, especially on historically underrepresented student groups in science, for whom campus climate and sense of belonging are strong predictors of student retention and degree completion in higher education (Seymour and Hewitt, 1997; Hausmann et al., 2007; Museus et al., 2008). CUREs research will profit from a close examination of the impact that CUREs have on the connection between attitudinal changes, proscience attitudes, and academic performance for nonmajors.

3. Although critical to education research interests, we are unaware of established techniques for assessing students' evidence-based decision-making abilities, the third objective for improvement among nonmajors. A future contribution to this field will be the development of a comprehensive tool to specifically assess both short-term and long-term changes in this competency.

Parallel comparisons between "cookbook" labs, student-led inquiry labs, discovery-based inquiry labs, and CUREs are another approach to investigating whether a CURE for nonmajors effectively achieves its three central goals. Comparisons will show whether observed shifts in performance or perceptions over the course of a semester are due to the CURE design specifically or whether students experience similar or even more positive changes in other lab models. Three design features of biology CUREs can be directly measured by the Laboratory Course Assessment Survey, which quantifies students' perceptions of collaboration, discovery and relevance, and iteration (Corwin et al., 2015). Alternatively, the Laboratory Observation Protocol for Undergraduate STEM will provide clear characterization of instructional practices teaching assistants enact in laboratories and can be used to obtain information about practices in different laboratory-teaching environments (Velasco et al., 2016). Future research should also emphasize which of the five characteristic elements of a CURE are best at achieving course goals and objectives over others using quasiexperimental design approaches. Dividing students by majors and nonmajors status will highlight differences between developing scientists (majors) and the scientifically literate citizenry (nonmajors; e.g., Brownell et al., 2012).

\section{OPPORTUNITIES TO COLLABORATE AND DISSEMINATE BEST PRACTICES FOR CURES FOR NONMAJORS}

Collaboration and dissemination of effective strategies are critical to the improvement of laboratory teaching and the implementation of CUREs for nonmajors. Although future research 
may support the notion that nonmajors CUREs are distinct entities from majors CUREs, we describe here the growing number of resources for developing and publicizing CUREs for majors. For example, CUREnet is a website that hosts a collection of tested examples of laboratory activities written by a diverse community composed of instructors, researchers, information technology specialists, and curriculum developers. One can browse projects according to relevant CURE features such as data type, student audience, and core competencies. One future direction for this community may be the formation of a CUREnet subgroup for nonmajors, committed to evaluating and promoting best practices for nonmajors specifically. Establishing such a community would require support for meetings, disseminating ideas, developing instruments, and forging collaborations between departments and institutions.

Many organizations promote the study of STEM education and offer platforms to disseminate ideas and research to instructors who teach broad audiences, from majors and nonmajors university students to high school science students. The Society for the Advancement of Biology Education Research is a group dedicated to developing evidence-based strategies to improve biology education, and they support education research by fostering collaborations among investigators. Their national meetings highlight hypothesis-driven research projects that examine all aspects of student learning and education practices. The National Association of Biology Teachers is another group that supports life sciences education with an emphasis on high school and undergraduate-level biology. Many national STEM conferences, such as the joint annual Evolution conference of the Society for the Study of Evolution, the Society of Systematic Biologists, and the American Society of Naturalists, feature separate breakout sessions for discipline-specific education research within the conference schedule. These large conferences are prime opportunities to present research and discuss scientific teaching with colleagues. In many cases, these conferences are ideal venues for introducing the concept of CUREs to a new audience of potential implementers-educators who will likely demand evidence of CURE efficacy.

Collaborative funding opportunities, such as the Research Coordination Network through the National Science Foundation, can also facilitate discussion among like-minded colleagues and lead to the publication of novel ideas. Using this funding, organizations can host education researchers and CURE curriculum developers to communicate research directions and teaching practices and share future initiatives across institutional and geographic boundaries.

\section{SUMMARY}

The goal of this workshop was to identify best practices for CUREs for nonmajors. Our determination of student outcomes was informed by recent research comparing nonmajors with majors. We also discussed the state of knowledge of best practices for nonmajors and used that to identify research priorities for the future.

We identified desired outcomes as 1) scientific research literacy skills, 2) proscience attitudes, and 3) evidence-based decision making. We described ways to directly and indirectly assess these student outcomes with the use of existing survey instruments, which will address the most pressing questions about the effect of CUREs on nonmajors students. Historically, research has not focused on nonmajors or analyzed nonmajors performance in response to different teaching methods, and so there is tremendous potential to support this critical group of students through evidence-based approaches. We hope this report provides instructors with the questions and the tools needed to start incorporating pedagogical research into their own inquiry-based teaching. Systemic efforts to collaborate and disseminate results among institutions will be essential to our national efforts to improve teaching with CURES specifically and to promote STEM disciplines more broadly.

\section{REFERENCES}

Alkaher, I., \& Dolan, E. L. (2014). Integrating research into undergraduate courses: current practices and future directions. In Sunal, D., Sunal, C., Zollman, D., Mason, C., \& Wright, E. (Eds.), Research in science education: Research based undergraduate science teaching (pp. 403-434). Charlotte, NC: Information Age.

Allum, N., Sturgis, P., Tabourazi, D., \& Brunton-Smith, I. (2008). Science knowledge and attitudes across cultures: a meta-analysis. Public Understanding of Science, 17(1), 35-54.

American Association for the Advancement of Science (2011). Vision and change in undergraduate biology education: A call to action. Washington, DC.

Auchincloss, L. C., Laursen, S. L., Branchaw, J. L., Eagan, K., Graham, M. Hanauer, D. I., ... Rowland, S. (2014). Assessment of course-based undergraduate research experiences: A meeting report. CBE-Life Sciences Education, 13(1), 29-40.

Bangera, G., \& Brownell, S. E. (2014). Course-based undergraduate research experiences can make scientific research more inclusive. CBE-Life Sciences Education, 13(4), 602-606.

Bascom-Slack, C. A., Arnold, A. E., \& Strobel, S. A. (2012). Student-directed discovery of the plant microbiome and its products. Science, 338(6106), 485-486.

Boyle, A., Maguire, S., Martin, A., Milsom, C., Nash, R., Rawlinson, S., ... Conchie, S. (2007). Fieldwork is good: the student perception and the affective domain. Journal of Geography Higher Education, 31(2), 299-317.

Brownell, S. E., Hekmat-Scafe, D. S., Singla, V., Seawell, P. C., Imam, J. F. C., Eddy, S. L., ... Cyert, M. S. (2015). A high-enrollment course-based undergraduate research experience improves student conceptions of scientific thinking and ability to interpret data. CBE-Life Sciences Education, 14(2), ar21.

Brownell, S. E., \& Kloser, M. J. (2015). Toward a conceptual framework for measuring the effectiveness of course-based undergraduate research experiences in undergraduate biology. Studies in Higher Education, 40(3), 525-544.

Brownell, S. E., Kloser, M. J., Fukami, T., \& Shavelson, R. (2012). Undergraduate biology lab courses: comparing the impact of traditionally based "cookbook" and authentic research-based courses on student lab experiences. Journal of Computer Science and Technology, 41(4), 36-45.

Chervenak, F. A., \& McCullough, L. B. (1990). Does obstetric ethics have any role in the obstetrician's response to the abortion controversy? American Journal of Obstetrics and Gynecology, 163(5), 1425-1429.

Cook, M., \& Mulvihill, T. M. (2008). Examining US college students' attitudes towards science: learning from non-science majors. Education Research Review, 3(1), 38

Corwin, L. A., Runyon, C., Robinson, A., \& Dolan, E. L. (2015). The Laboratory Course Assessment Survey: A tool to measure three dimensions of research-course design. CBE-Life Sciences Education, 14(4), ar37.

Cotner, S., \& Hebert, S. (2016). Bean beetles make biology research sexy. American Biology Teacher, 78(3), 233-240.

Cotner, S., Thompson, S., \& Wright, R. (2017). Do biology majors really differ from non-STEM majors? CBE-Life Sciences Education (in press).

Desai, K. V., Gatson, S. N., Stiles, T. W., Stewart, R. H., Laine, G. A., \& Quick, C. M. (2008). Integrating research and education at research-extensive universities with research-intensive communities. Advances in Physiology Education, 32(2), 136-141. 
Espinosa, L. (2011). Pipelines and pathways: women of color in undergraduate STEM majors and the college experiences that contribute to persistence. Harvard Educational Review, 81(2), 209-241.

Feinstein, N. W., Allen, S., \& Jenkins, E. (2013). Outside the pipeline: Reimag ining science education for nonscientists. Science, 340(6130), 314-317.

Fraser, B. J. (1978). Development of a test of science-related attitudes. Science Education, 62(4), 509-515.

Glynn, S. M., Brickman, P., Armstrong, N., \& Taasoobshirazi, G. (2011). Science motivation questionnaire II: Validation with science majors and nonscience majors. Journal of Research in Science Teaching, 48(10), 1159 1176

Gormally, C., Brickman, P., \& Lutz, M. (2012). Developing a Test of Scientific Literacy Skills (TOSLS): measuring undergraduates' evaluation of scientific information and arguments. CBE-Life Sciences Education, 11(4), 364-377.

Hanauer, D., Frederick, J., Fotinakes, B., \& Strobel, S. (2012). Linguistic analysis of project ownership for undergraduate research experiences. CBELife Sciences Education, 11(4), 378-385.

Hanauer, D., \& Hatfull, G. (2015). Measuring networking as an outcome variable in undergraduate research experiences. CBE-Life Sciences Education, 14(4), ar38.

Hathaway, R. S., Nagda, B. A., \& Gregerman, S. R. (2002). The relationship of undergraduate research participation to graduate and professiona education pursuit: an empirical study. Journal of College Student Development, 43(5), 614-631.

Hausmann, L. R., Schofield, J. W., \& Woods, R. L. (2007). Sense of belonging as a predictor of intentions to persist among African American and white first-year college students. Research in Higher Education, 48(7), 803-839.

Hernandez, P. R., Schultz, P. W., Estrada, M., Woodcock, A., \& Chance, R. C. (2013). Sustaining optimal motivation: a longitudinal analysis of interventions to broaden participation of underrepresented students in STEM. Journal of Educational Psychology, 105(1), doi: 10.1037/a0029691

Jordan, T. C., Burnett, S. H., Carson, S., Caruso, S. M., Clase, K., DeJong, R. J., ... Elgin, S. C. (2014). A broadly implementable research course in phage discovery and genomics for first-year undergraduate students. mBio 5(1), e01051-13.

Kahan, D. (2010). Fixing the communications failure. Nature, 463(7279) 296-297.

Kloser, M. J., Brownell, S. E., Shavelson, R. J., \& Fukami, T. (2013). Effects of a research-based ecology lab course: a study of nonvolunteer achievement, self-confidence, and perception of lab course purpose. Journal of Computer Science and Technology, 42(3), 72-81.

Klymkowsky, M. W. (2005). Content versus process: Is this a fair choice? Can nonmajors courses lead to biological literacy? Do majors courses do any better? Cell Biology Education, 4(3), 196-198.

Knight, J. K., \& Smith, M. K. (2010). Different but equal? How nonmajors and majors approach and learn genetics. CBE-Life Sciences Education, 9(1), 34-44.

Larson, H. J., Cooper, L. Z., Eskola, J., Katz, S. L., \& Ratzan, S. (2011). Addressing the vaccine confidence gap. Lancet, 378(9790), 526-535.

Lopatto, D. (2007). Undergraduate research experiences support science career decisions and active learning. CBE-Life Sciences Education, 6(4), 297-306. doi: 10.1187/cbe.07-06-0039

Martin, B., \& Richards, E. (1995). Scientific knowledge, controversy, and public decision-making. In Jasanoff, S., Markle, G., Petersen, J., \& Pinch, T. (Eds.), Handbook of science and technology studies (pp. 506-526). Thousand Oaks, CA: Sage.

Medina, S .R, Ortlieb, E., \& Metoyer, S. (2014). Life science literacy of an undergraduate population. American Biology Teacher, 76(1), 34-41.

Miller, J. D. (2004). Public understanding of, and attitudes toward, scientific research: what we know and what we need to know. Public Understanding of Science, 13(3), 273-294.

Minner, D. D., Levy, A. J., \& Century, J. (2010). Inquiry-based science instruction-what is it and does it matter? Results from a research synthesis years 1984 to 2002. Journal of Research in Science Teaching, 47(4), 474-496.

Museus, S. D., Nichols, A. H., \& Lambert, A. D. (2008). Racial differences in the effects of campus racial climate on degree completion: a structural equation model. Review of Higher Education, 32(1), 107-134.

Nehm, R. H., \& Reilly, L. (2007). Biology majors' knowledge and misconceptions of natural selection. BioScience, 57(3), 263-272.
Oreskes, N. (2004). Science and public policy: What's proof got to do with it? Environmental Science \& Policy, 7(5), 369-383.

Osborne, J., Simon, S., \& Collins, S. (2003). Attitudes towards science: A review of the literature and its implications. International Journal of Science Education, 25(9), 1049-1079.

Partin, M. L., Underwood, E. M., \& Worch, E. A. (2013). Factors related to college students' understanding of the nature of science: Comparison of science majors and nonscience majors. Journal of College Science Teaching, 42(6), 89-100.

Paz-y-mino, C., \& Espinosa, A. (2010). Integrating horizontal gene transfer and common descent to depict evolution and contrast it with "common design." Journal of Eukaryotic Microbiology, 57(1), 11-18.

President's Council of Advisors on Science and Technology. (2012). Engage to excel: Producing one million additional college graduates with degrees in STEM. Washington, DC: Executive Office of the President. https:// obamawhitehouse.archives.gov/sites/default/files/microsites/ostp/pcast -engage-to-excel-final_2-25-12.pdf (accessed 1 October 2016).

Russell, S. H., Hancock, M. P., \& McCullough, J. (2007). Benefits of undergraduate research experiences. Science, 316(5824), 548-549.

Semken, S., \& Freeman, C. B. (2008). Sense of place in the practice and assessment of place-based science teaching. Science Education, 92(6), 1042-1057

Seymour, E., \& Hewitt, N. M. (1997). Talking about leaving. Boulder, CO Westview.

Shaffer, C. D., Alvarez, C., Bailey, C., Barnard, D., Bhalla, S., Chandrasekaran C., ... Du, C. (2010). The Genomics Education Partnership: Successful integration of research into laboratory classes at a diverse group of undergraduate institutions. CBE-Life Sciences Education, 9(1), 55-69.

Shaffer, C. D., Alvarez, C. J., Bednarski, A. E., Dunbar, D., Goodman, A. L., Reinke, C., \& Barnard, D. (2014). A course-based research experience: how benefits change with increased investment in instructional time. CBE-Life Sciences Education, 13(1), 111-130

Shapiro, C., Moberg-Parker, J., Toma, S., Ayon, C., Zimmerman, H., Roth-Johnson, E. A., ... Sanders, E. R. (2015). Comparing the impact of course-based and apprentice-based research experiences in a life science laboratory curriculum. Journal of Microbiology \& Biology Education, 16(2), 186-197. doi: 10.1128/jmbe.v16i2.1045

Shortlidge, E. E., \& Brownell, S. E. (2016). How to assess your CURE: a practical guide for instructors of course-based undergraduate research experiences. Journal of Microbiology \& Biology Education, 17(3), 399-408.

Smith, D. (2004). Issues and trends in higher education biology fieldwork. Journal of Biological Education, 39(1), 6-10. doi: 10.1080/00219266.2004 9655946

Smith, W. S., Gould, S. M., \& Jones, J. A. (2004). Starting the semester at odds: educators versus students' reasons for studying science. Journal of College Science Teaching, 34, 44-49

Spell, R. M., Guinan, J. A., Miller, K. R., \& Beck, C. W. (2014). Redefining authentic research 11 experiences in introductory biology laboratories and barriers to their implementation. CBE-Life Sciences Education, 13, 102-110.

Sundberg, M. D., \& Dini, M. L. (1993). Science majors vs nonmajors: Is there a difference? Journal of College Science Teaching, 22(5), 299-304.

Sundberg, M. D., Dini, M. L., \& Li, E. (1994). Decreasing course content improves student comprehension of science and attitudes towards science in freshman biology. Journal of Research in Science Teaching, 31(6), $679-693$.

Velasco, J. B., Knedeisen, A., Xue, D., Vickrey, T. L., Abebe, M., \& Stains, M. (2016). Characterizing instructional practices in the laboratory: The laboratory observation protocol for undergraduate STEM. Journal of Chemical Education, 93(7), 1191-1203.

Wood, W. B. (2003). Inquiry-based undergraduate teaching in the life sciences at large research universities: A perspective on the Boyer Commission Report. Cell Biology Education, 2(2), 112-116.

Wright, R. L. (2005). Points of view: Content versus process: Is this a fair choice? Undergraduate biology courses for nonscientists: Toward a lived curriculum. Cell Biology Education, 4(3), 189-196.

Zydney, A. L., Bennett, J. S., Shahid, A., \& Bauer, K. W. (2002). Impact of undergraduate research experience in engineering. Journal of Engineering Education, 91(2), 151-157. 